ISSN 2078-6441. Вісник Львівського університету. Серія географічна. 2018. Випуск 52. С. 251-265.

Visnyk of the Lviv University. Series Geography. 2018. Issue 52. P. 251-265.

http://dx.doi.org/10.30970/vgg.2018.52.10191

$631.4: 911.6(477.83)$

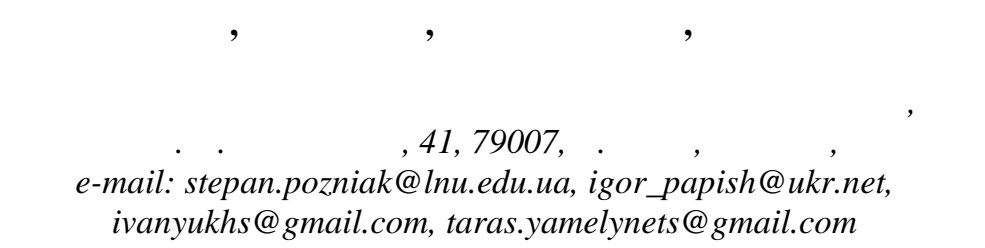

хем грунтово-геогр фічного р йонув ння ьвівської обл. створен н принцип х структурного підходу до просторової орг ніз ції грунтового покриву. ритерієм виділення одиниць різного р нгу, їхньої просторово-генетичної х р ктеристики $є$ якісно-генетичні пок зники грунтового покриву з н лізом просторового розміщення грунтових комбін цій і структур. з пропонов ній схемі р йонув ння виділено т кі т ксономічні одиниці: грунтово-геогр фічн кр їн, грунтово-біоклім тичн зон (гірський пояс), кр й, округ (гірськ грунтов обл сть), р йон, м сив.

бов'язковим критерієм для всіх т ксономічних р нгів грунтово-геогр фічного р йонув ння $\epsilon$ тип мезоструктур грунтового покриву (просторово-геометричні х $\mathrm{p}$ ктеристики елемент рних грунтових ре лів т їхніх просторово-територі льних структур, т кож домінув ння певного кл су грунтових комбін цій).

меж х ьвівської обл. виділено дві грунтово-геогр фічні кр їни: хідноєвропейську рівнину т рп ти; три грунтово-біоклім тичні зони: моренно-з ндрову (попільнякову) зону міш них лісів, широколистяно-лісову, лісостепову (лесову) і гірсько-буроземний пояс; шість грунтових кр їв: лополіський, олинський, озтоцько- пільський, хідноподільський, ередк рп тський височинний, рп тський гірський; 13 грунтових округів і 4 обл сті.

лючові слов : р йонув ння, структур грунтового покриву, зон, кр й, округ, ьвівськ обл.

основі грунтово-геогр фічного р йонув ння є грунтово-генетичний принцип виділення просторових структур, великом сшт бні т дет льні грунтові к рти, к рти структур грунтового покриву ьвівської обл. [3, 8], т кож н ліз спеці льних к рт (геологічних, геоморфологічних, л ндш фтних, клім тичних, геобот нічних, четвертинних відкл дів). скільки грунтов неоднорідність, н віть у р зі дет льного к ртогр фув ння структури грунтового покриву, є прит м нною рисою не тільки грунтового покриву певних регіонів, різних грунтових структур, грунтових комбін цій, й окремих грунтів, то структурний підхід до $\mathrm{p}$ йонув ння з стосов ний до всіх т ксономічних одиниць р йонув ння.

грунтово-геогр фічному р йонув нні будову грунтового покриву розгляд ють н вищому орг ніз ційному рівні, х р ктеризуючи не просторово-типологічну, структурну відмінність різних регіон льних одиниць грунтового покриву. е р йонув ння можн легко д птув ти для міжгоспод рської т внутрішньогоспод рської орг ніз ції сільськогоспод рської території, т кож пл нув ння сівозмін, формув ння порівняно однорідних у просторовому і генетичному зн ченні земельних м сивів.

(C) озняк ., піш ., в нюк ., мелинець ., 2018 
3 стосув ння т кого підходу поляг є в тому, що він $є$ фунд мент льною основою для обгрунтув ння регіон льних схем і проектів р ціон льного природокористув ння, екологіз ції проектів міжгоспод рського і внутрішньогоспод рського землевпорядкув ння, формув ння природно-з повідного фонду регіону, для перспективного регіон льного пл нув ння, моніторингу і прогнозув ння розвитку грунтово-територі льних структур н 3 с д х використ ння грунтово-просторових х р ктеристик [6].

о грунтово-геогр фічного $\mathrm{p}$ йонув ння, розробленого пр цівник ми к федри грунтозн вств і геогр фії грунтів (2016), з стосов но структурний підхід, 3 яким оцінюють структурну відмінність різних регіон льних одиниць грунтового покриву, просторові х р ктеристики грунтового покриву. схемі цього р йонув ння виділено т кі т ксономічні одиниці різного р нгу: міжрегіон льні - грунтово-геогр фічн кр їн ; зон льні - грунтово-біоклім тичн зон, гірський грунтово-висотний пояс; зон льні грунтовий кр й, округ, р йон, м сив [6, 7].

p зі виділення т ксономічних одиниць, їхніх х р ктеристик т ре лів поширення вр ховують генезу, історію розвитку, еволюцію грунтово-л ндш фтної структури, н лізують вз ємозв'язки і вз ємодію основних чинників грунтотворення i, що н йв жливіше, генетико-геометричні х р ктеристики структур грунтового покриву т їхню типіз цію [10].

рунтово-геогр фічн кр їн предст влен мег структур ми грунтового покриву, для неї х р ктерне поєдн ння специфічних типів морфоструктур і кл сів л ндш фтів: рівнинн - широтн зон льність л ндш фтів 3 покривним х р ктером грунтовотериторі льної структури (поєдн ння, в рі ції, комплекси і плямистості), гірськ висотн поясність л ндш фтів з моз їчним х р ктером грунтової структури (моз їки, т шети, зміш ні елементи структур - поєдн ння-моз їки).

рунтово-біоклім тичн зон (гірський пояс) - ре л поширення зон льного типу грунтових м кроструктур зі специфічним просторовим поєдн нням зон льного грунтового типу, бо типів і супутніх їм інтр зон льних грунтів.

рунтовий кр й - вирізняється з кономірним поєдн нням декількох генетичних типів рельєфу т є сукупністю відповідних форм структур грунтового покриву, у скл ді яких домінують ті чи інші кл си грунтових комбін цій (комплекси, плямистості, поєдн ння, в рі ції, моз їки і т шети), тобто типологічним критерієм його виділення є якісно-просторов х р ктеристик структури грунтового покриву.

рунтовий округ (гірськ грунтов обл сть) м є певний генетичний тип рельєфу, який зумовлює відповідне поєдн ння грунтотворних порід і грунтів т , як н слідок, $\mathrm{x}$ р ктерну генетико-геометричну будову грунтових комбін цій і грунтових структур. ормув ння округу з лежить від комплексу місцевих чинників утворення просторової неоднорідності грунтового покриву, передусім літолого-геоморфологічних і гідрологічних.

бов'язковим критерієм для усіх т ксономічних р нгів грунтово-геогр фічного p йонув ння $\epsilon$ тип мезоструктур грунтового покриву (просторово-геометричні х р ктеристики елемент рних грунтових ре лів т їхніх просторово-територі льних структур, т кож домінув ння певного кл су грунтових комбін цій) $[6,7]$. хем грунтово-геогр фічного р йонув ння (див. рисунок) відобр ж є поширення т ксономічних одиниць грунтового покриву, не систем тичних одиниць грунтів (типів і підтипів). 
Грунтово-географічне районування Львівської обл.: структура та принципи

\begin{tabular}{|c|c|c|c|c|c|c|c|c|c|c|c|c|c|}
\hline 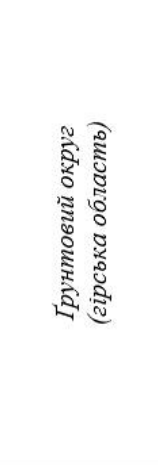 & 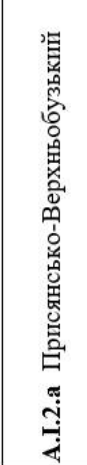 & 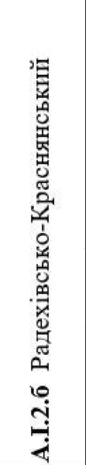 & 资 & 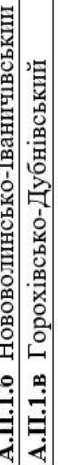 & 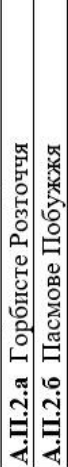 & 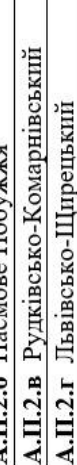 & 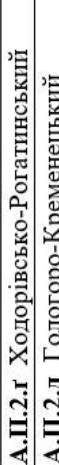 & 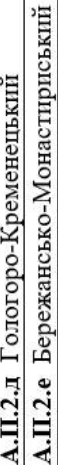 & 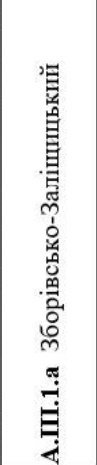 & 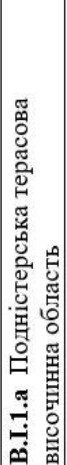 & 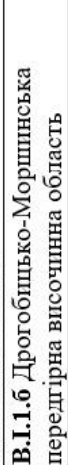 & 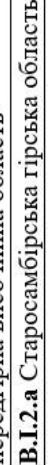 & 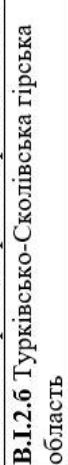 \\
\hline 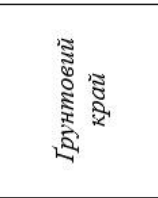 & & & & 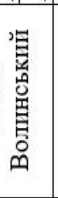 & & 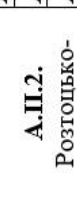 & 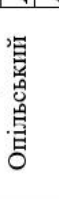 & & 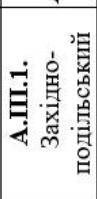 & ف. & 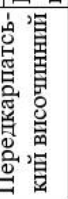 & فำ & 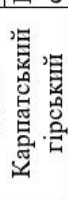 \\
\hline 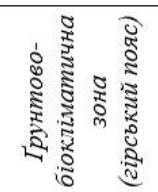 & - & 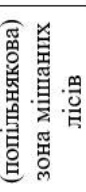 & & & 日 & 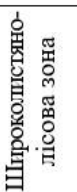 & & & 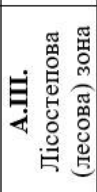 & & فَ & 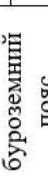 & \\
\hline 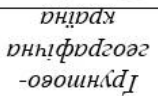 & \multicolumn{9}{|c|}{ 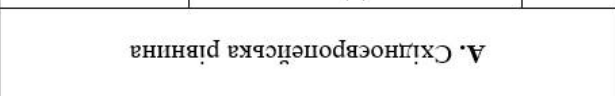 } & \multicolumn{4}{|c|}{ ицешdеу 'g } \\
\hline
\end{tabular}

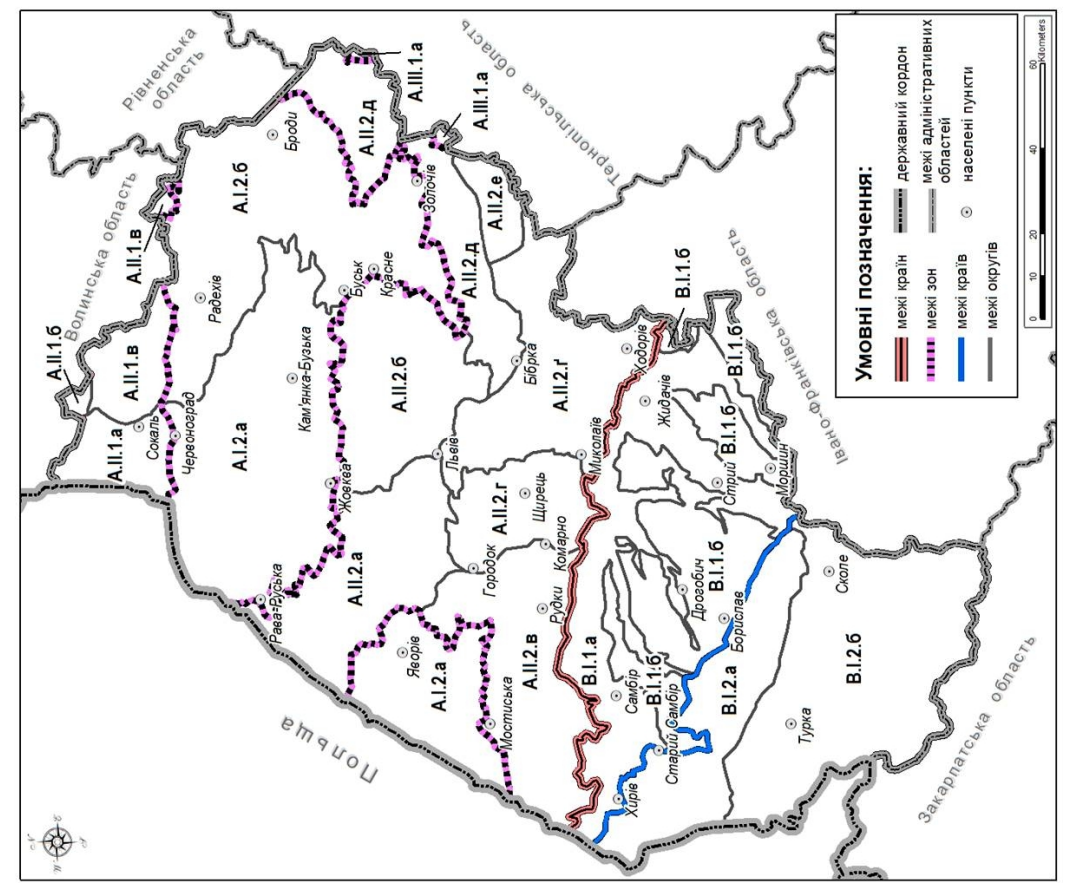

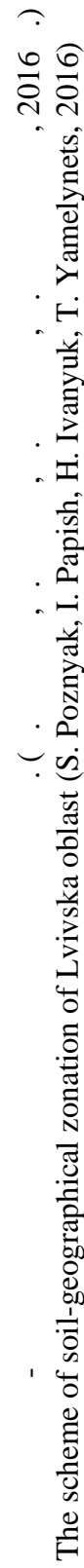


сновними чинник ми формув ння структурних відмінностей грунтового покриву ьвівської обл. є рельєф і літологія грунтотворних т підстильних порід. л сне вони через перерозподіл біоклім тичних і гідрологічних умов спричинили формув ння скл дної моз їки грунтового покриву обл сті.

меж х ьвівської обл. виділяють дві грунтово-геогр фічні кр їни ( хідноєвропейськ рівнин т рп ти), три грунтово-біоклім тичні зони (моренно-з ндров (попільняков ) зон міш них лісів, широколистяно-лісов, лісостепов (лесов )) i гірсько-буроземний пояс, шість грунтових кр їв ( лополіський, олинський, озтоцько- пільський, хідноподільський, ередк рп тський височинний, рп тський гірський), т кож 13 грунтових округів і 4 обл сті (див. рисунок).

рунтово-геогр фічн кр їн хідноєвропейськ рівнин ( ) у меж х ьвівської обл сті поєднує три грунтово-біоклім тичні зони: моренно-з ндрову (попільнякову) зону міш них лісів, широколистяно-лісову т лісостепову (лесову).

.. оренно-з ндров (попільняков) зон міш них лісів. рунтовий покрив зони предст влений перев жно чергув нням різкоконтр стних і контр стних грунтових мезо- і мікрокомбін цій з одно- і двостороннім тип ми зв'язку між компонент ми. чинник ми диференці ції грунтового покриву перев ж ють гідроморфно-диференційов ні, літогенні, літогенно-гідроморфно-диференційов ні, зрідк - ерозійногідроморфно-диференційов ні комбін ції. вл стивостями грунтів, що визн ч ють диференці цію грунтового покриву і виникнення грунтових комбін цій, перев ж ють різкоконтр стні дерново-підзолисто-гідроморфні і літогенно-дерново-підзолистогідроморфні грунтові комбін ції. ерново-підзолисто-болотний підкл с грунтових комбін цій охоплює грунти, які відрізняються з ступенем розвитку двох процесів опідзолення і оглеєння. ругий кл с комбін цій дод тково ще й диференціюють 3 ступенем розвитку гумусового процесу, н сиченням основ ми і к рбон тністю [7].

..2. лополіський кр й крейдяно-флювіогляці льних контр стних літогенногідроморфно-диференційов них $i$ вторинно-н сичених дерново-підзолисто-болотних поєдн нь-комплексів імоз їк рендзин з чорнозем ми к рбон тними.

івнічн меж кр ю простяг ється від кордону 3 ольщею по т ких н селених пункт х ьвівської обл.: елз- ервоногр д, д лі н схід, в інших обл стях по т ких пункт $\mathrm{x}$ : ерестечко- озин- ерб - строг- рупець- оровець. івденно-з хідн і південн межі - від кордону з ольщею по долині p. ишня до удової ишні, д лі долин ми рік в дівк і оброст нк до озточчя. ин ючи розчленов ну флювіогляці льними долин ми широке озтоцьке п смо, продовжується в н прямі н обросин- овкву- трептів- линяни- олочів- лесько- сенів- уховолю, поз меж ми обл сті: ременець- епетівку- ервоний віт- вичі. евеликий природний нкл в поліських л ндш фтів ( дсяння) простяг ється між янсько- ністерською височиною і озточчям [2].

е пл стово- кумулятивн рівнин, розділен розчленов ними прохідними долин ми 3 флювіогляці льними відкл д ми, скл ден верхньокрейдовими відкл д ми (мергелями), що покриті з ндрово- люві льними ос довими пород ми; відкл ди крейди з ляг ють зн чно глибше, ніж в інших ч стин х кр ю.

. .2. рисянсько- ерхньобузький низинний моренно-з ндровий округ дрібноре льних поєдн нь-комплексів дерново-сл бко-, середньопідзолистих, ясно-сірих лісових грунтів, рендзин $i$ дернових глейових грунтів з лучними, лучно-болотними $i$ торфово-болотними грунт ми. 
ериторія округу скл д ється з двох, порівняно ізольов них озточчям, природних м сивів: рисянського ( дсяння) i ерхньобузького. хідн меж цього округу ( ерхньобузький м сив) досить звивист і простяг ється орієнтовно по т ких н селених пункт х: п с- ур'я- околівк - ониковиця- мельове- т нісл вчик- бичіоздимир.

росторов неоднорідність (скл дність і контр стність) грунтового покриву зумовлен процес ми опідзолення, оглеєння і літологічною моз їчністю порід. еглибоке з ляг ння крейдяних мергелів під товщею флювіогляці лу призводить до формув ння у ерхньобузькій ч стині округу вторинно-н сичених поєдн нь-комплексів дерновосл бко-, дерново-середньопідзолистих і ясно-сірих лісових грунтів з лучними, дерновими глейовими і торфово-болотними грунт ми. північно-з хідній ч стині округу, де крейдяні мергелі ч сто виходять н поверхню, утворилися літогенно-диференційов ні моз їки рендзин і чорноземів к рбон тних. явність лесових п сом серед 3 ндрової рівнини є причиною формув ння помірно контр стних поєдн нь ясно-сірих лісових $\mathrm{i}$ дерново-сл бкопідзолистих грунтів. зниженнях рельєфу i долин х рік поширені контр стні комплекси дернових глейових, лучно-болотних і торфово-болотних грунтів.

межиріччі хідного угу і вині (між м. м’янк - узьк і с. уринк ) н йбільше поширений гідроморфний комплексний грунтовий покрив.

. 2.б дехівсько- р снянський підвищений крейдяно-флювіогляці льно-д вньолюві льний округ скл дних поєдн нь-моз їк дерново-сл бко-, середньопідзолистих грунтів з рендзин ми $і$ чорнозем ми к рбон тними; поєдн нь-в рі цій чорноземів типових неглибоких $i$ глибоких з лучними к рбон тними грунт ми; морфних комплексів лучно-болотних і болотних торфових грунтів.

пецифік округу в тому, що крейдяні мергелі виходять безпосередньо н денну поверхню. они дуже звітрені, м’які, потужні. ише місцями мергелі перекриті флювіогляці льними піск ми. рейдяні відкл ди тріщинув ті, тому регіон порівняно добре дренов ний з м лою кількістю гідроморфних комплексів. сновними причин ми диференці ції грунтового покриву є літогенн неоднорідність території, що зумовлює виникнення скл дного грунтового покриву з домінув нням моз їк. умови хвилястого і горбистого рельєфу ч сто поширені скл дніші поєдн ння-моз їки (перший порядок скл дності) дерново-сл бко- і середньопідзолистих грунтів з рендзин ми і чорнозем ми к рбон тними. хвилястих вододільних поверхнях з добре вир женим мікрорельєфом формуються гр нулометрично-диференційов ні моз їки дерново-підзолистих грунтів і рендзин.

північній ч стині округу перев ж ють підвищені сл бкохвилясті території, утворені крейдовими мергелями, з перев жним типом грунтових комбін цій - моз їк ми гумусов ності. ричиною їхньої неоднорідності є потужність звітреної товщі крейдяних відкл дів і глибин гумусов ності профілю. рідк серед моз їчного грунтового покриву, перев жно н вододіл х, поширені плямистості дерново-сл бко- і середньопідзолисті грунти. зниженнях рельєфу, долин х і з пл в х рік незн чні площі з йняті гідроморфними комплекс ми 3 торфовищ низинних, лучно-болотних i болотних грунтів.

оєДН ння-моз їки сірих лісових грунтів, рендзин і чорноземів к рбон тних не м ють зн чного поширення і приурочені перев жно до місць підвищеної лесової кумуляції. південній, т кож південно-східній ч стин х p йону н йбільшу площу 3 йм ють поєдн ння-в рі ції гумусов ності, скл дені чорнозем ми типовими неглибо- 
кими і глибокими м логумусними н лесових пород х з лучно-чорноземними і лучними к рбон тними грунт ми. нколи тр пляються гідроморфно-диференційов ні комплекси дернових, дернових глейових грунтів з лучно-болотними т болотними грунт ми.

ироколистяно-лісов прунтово-біоклім тичн зон простяг ється н 3 хід i південний з хід від лісостепової зони і приурочен до н йбільш підвищених і розчленов них р йонів олинської і одільської височин.

езн чний відсоток лучно-степових чорноземів типових у структурі грунтового покриву (до $10 \%$ ), приуроченість їхніх ре лів перев жно до д вніх прохідних долин, н дз пл вних тер с, з звич й, середнього рівня, зн чних знижень серед розчленов ного рельєфу, до м сивів земель з д вньою землеробською культурою свідчить про н лежність цих територій до зони широколистяних лісів східноєвропейського перехідного типу.

ля цієї зони х р ктерним є зн чне зволоження (600-700 мм з рік), грунти ч сто оглеєні т вилугув ні. рунтовий покрив не $є$ типологічно строк тим. омінують сильно- і сл бкоопідзолені грунти, зрідк тр пляються різні види чорноземів типових (перев жно неглибокі й середньоглибокі, м логумусні т сл бкогумусов ні). структурі лісо-лучних л ндш фтів, зокрем , н узліссях чи опіллях, ч сто простежуються т к зв ні лісостепові вікн 3 чорнозем ми регр дов ними, зн чне поширення м ють еродов ні грунти. учні, лучно-болотні й болотні грунти поширені в долин х рік, широких і вузьких б лк х, н дз пл вних тер с х, формуючи нижні яруси грунтових мезокомбін цій.

умов низовинного рельєфу і н тер с х перев ж ють геоморфологічно зумовлені плямистості, прості в рі ції бо поєдн ння-в рі ції чорноземів регр дов них з чорнозем ми типовими і лучно-чорноземними грунт ми. широких сл бкорозчленов них пл то ч сто поширені прості поєдн ння чи біогенні т шети темно-сірих опідзолених грунтів з чорнозем ми опідзоленими і регр дов ними. великій території з сильно і глибоко розчленов ним рельєфом перев ж ють скл дні ерозійно-деревоподібні поєдн ння сильноопідзолених грунтів н вододіл х 3 їхніми змитими і н митими н лог ми н схил х і б лк х. обто невеликі 3 площею елементи лісостепового л ндш фту з відповідною структурою грунтового покриву не х р ктерні для грунтового кр ю, є н слідком біоклім тичної неоднорідності території, зумовленої просторовими комбін ціями форм і елементів мезорельєфу.

широколистяно-лісовій зоні висотновпорядков них ерозійно-деревоподібних поєдн нь і поєдн нь-в рі цій опідзолення і оглеєння в меж х ьвівської обл. виділяємо олинський і озтоцько- пільський грунтово-геогр фічні кр ї.

. .1. олинський кр й висотновпорядков них ерозійно-деревоподібних поєдн нь сірих лісових $і$ темно-сірих опідзолених глеюв тих грунтів, чорноземів регр дов них $i$ типових неглибоких $m$ середньоглибоких глибинно-глеюв тих пологоув листої рівнини.

е своєрідний широколистяно-лісовий “острів” серед моренно-з ндрової (попільнякової) зони міш них лісів. ежі кр ю збіг ються з геоморфологічною підобл стю олинської денуд ційної височини [4], укритої, здебільшого, легкими з гр нулометричним скл дом лесоподібними суглинк ми. облизу північної т південної меж кр ю, неглибоко від денної поверхні з ляг $\epsilon$, іноді й виходить н денну поверхню, крейдяний мергель. середній ч стині височини, н з ході олинського кр ю, поширений 
тектонічний вузький прогин п леозойської основи, що відобр ж ється в низовинному пологохвилястому рельєфі з розвиненими тер с ми, широтному розвитку бічних приток гідрогр фічної мережі, особливостях структури грунтового покриву. 3 хідній ч стині височини, н лінії в ничі- уцьк н явні сліди окського зледеніння (по долин х річок хідний уг і уг ). рогр фічн неоднорідність земної поверхні є першопричиною просторової неоднорідності структури грунтового покриву.

грунтово-геогр фічним р йонув нням [5] територія олинської височини повністю н лежить до риполіського грунтового округу, 3 грогрунтовим [9] - уцькоівненського грогрунтового р йону, що є некоректним, н н шу думку, з погляду як т ксономічної невідповідності, т к і просторової орг ніз ції грунтового покриву території. олинський грунтовий кр й неоднорідний 3 структурою грунтового покриву т історією його формув ння, тому потребує просторової диференці ції н рівні грунтових округів.

- .1. бузький ув листо-тер совий округ висотновпорядков них поєдн ньв рі цій чорноземів регр дов них, чорноземів типових неглибоких $і$ середньоглибоких глибинно-глеюв тих пологоув листого пл то 3 лучно-чорноземними $i$ лучними глибокими грунт ми низькихн дз пл вних тер с і днищ, широких блок.

круг поширений н 3 хід від р. хідний уг. ого поверхня вищ, ніж східн ч стин ок льського п см ( рт ківськ), одн к більш рівнинн і м йже не м $\epsilon$ пл корних лісів (н межиріччях) з сірими лісовими грунт ми. ерхній лесовий ярус утворився після окського зледеніння з перев жними висот ми до 230 м. його поверхні є численні вододільні підвищення і розлогі зниження (видолинки, тер си, 6 лки), місцями - яри т промивини. ндш фтн структур досить строк т , вир жен вододільно-хвилястими місцевостями з темно-сірими опідзоленими грунт ми і чорнозем ми опідзоленими н з ході; місцевостями розлогих знижень і схилів 3 регр дов ними чорнозем ми й чорнозем ми неглибокими і середньоглибокими глибинноглеюв тими т видолинк ми з лучно-чорноземними грунт ми. ля середньотер сового ярусу х р ктерні місцевості другої тер си з близьким з ляг нням грунтових вод i розвитком округло- ре льних плямистостей чорноземів лучних з лучно-чорноземними грунт ми т місцевості третьої тер си, скл деної типовими лес ми з плямистостями чорноземів типових глибоких і середньоглибоких, перев жно м логумусних. ижньотер совий ярус вир жений перев жно супіщ ними 3 пл в ми з моз їк ми дернових грунтів, іноді лучно-болотними комплекс ми, місцевостями першої тер си, з звич й піщ ної, з підзолисто-гідроморфними плямистостями дерново-сл бкопідзолистих грунтів, які місцями вкриті свіжими субор ми.

- .1.б ововолинсько- в ничівський моренно-тер сово-ув листий округ висотновпорядков них ерозійно-деревоподібних простих поєдн нь сірих лісових грунтів 3 чорнозем ми опідзоленими і регр дов ними підвищеного хвилястого пл то, $m$ кож скл дних підзолисто-гідроморфних поєдн нь-комплексів сірих лісових, дерново-сл бкоі середньопідзолистих грунтів з лучними глибокими грунт ми спільних середньотер совихмісцевостей рік хідний уг $i$ уг.

рунтовий округ поширений н схід від хідного угу до межі окського зледеніння (пр вий берег р. уг ), лише невеликою ділянкою предст влений у північній ч стині ьвівської обл. івденн меж округу ч стково проник є н лівий берег хідного угу, н північ від сіл едорівці т тенятин ьвівської обл. круг рівнинний, проте неоднорідний з структурою грунтового покриву, що зумовлено рельєфом території, 
літологією грунтотворних порід і впливом зледеніння. н чн комплексність грунтового покриву зумовлен т кож мерзлотними явищ ми. долині уги сформув лися лінійно-округлі літогенно-гідроморфні комплекси рендзин з торфово-болотними і торфовими грунт ми.

- .1.в орохівсько- убнівський горбисто-ув листий грунтовий округ перев жно висотно-впорядков них ерозійно-деревоподібних поєдн нь ясно-сірих $i$ сірих лісових грунтів н горбистих м сив х $і$ сп дистих довгих схил х з темно-сірими опідзоленими грунт ми і чорнозем ми опідзоленими н пологіших прирічкових схил $x$.

тер сових комплекс х уздовж річок ип, олодеж і тир поширені поєдн нняв рі ції чорноземів регр дов них і типових глибинно-глеюв тих глибоких. широких долин х рік розвинулися гідроморфно-болотні комплекси торфово-болотних грунтів і торфовищ глибоких. лесовому ярусі, у східній ч стині ок льського п см ( pт ківськ сторон ), перев ж ють вододільно-хвилясті місцевості з висотновпорядков ними ерозійно-деревоподібними поєдн ннями сірих лісових і темно-сірих опідзолених грунтів.

е горбисто-п смовий (особливо н 3 ході) лесовий р йон 3 н йбільшими бсолютними висот ми н олинській лесовій височині, густою і глибокою ерозійною розчленов ністю (н д є р йону вир зного горбистого вигляду) і зн чним поширенням еродов них грунтів у скл ді грунтових поєдн нь, т кож н йбільш лісистий регіон (до $20 \%$ г г льної території р йону), особливо н схід від з лізничної колії ьвів- уцьк.

з ході обмежений p. хідний уг і виток ми р. уг, у південній ч стині - лим оліссям, зокрем , долиною р. удилівк . круг простяг ється вздовж лого олісся вузькою довгою смугою у формі т к зв ного південного висотного в лу олинської ерозійної лесової височини з підвищеним з ляг нням крейдяного мергелю.

. .2. озтоцько- пільський кр й висотновпорядков них ерозійно-деревоподібних поєдн нь дерново-підзолистих і ясно-сірих лісових глеюв тих грунтів з темно-сірими опідзоленими глеюв тими грунт ми, чорнозем ми опідзоленими поверхнево-глеюв тими і глейовими, рендзин ми і глейовими грунт ми горбисто-лісистого озточчя й пілля, $m$ кож ерозійно-гідрогенно-диференційов них поєдн нь-в рі иій темно-сірих опідзолених глеюв тих $і$ глейових грунтів з чорнозем ми текстурно-диференційов ними глеюв тими і глейовими лесових п сом і пл то.

івнічн меж кр ю проведен по лому оліссю, південн - уздовж лівого борту долини ністр i тривігору. 3 ходу н схід грунтовий кр й простяг ється від р. ян н кордоні з ольщею до р. оропець н оділлі. території з кономірно поєдн ні дві групи опільських л ндш фтів: горбогірно-лісові і горбисто-п смові. ерші охоплюють озточчя, видівське, ологірське, ерхньобузьке п см , еремишлянське, ібрське, тільське, ременецьке, т кож ереж нське, орож нське і он стириське горбогір'я. рім х р ктерного для них глибокого розчленув ння поверхні, вони м ють н йвищі н рівнині бсолютні висоти (до 400 м), м лопотужний лесовий покрив і зн чний прояв площинної т лінійної ерозій, які сприяли утворенню висотновпорядков них ерозійно-деревоподібних форм грунтових поєдн нь опідзолення і оглеєння. руг груп рівнинних опільських л ндш фтів охоплює смове обужжя, янськоністерську і ородоцько- ом рнівську п смові височини, ьвівське і одорівське пілля. ут поширені плоскі, бо злегк хвилясті лесові місцевості з сірими лісовими, темно-сірими опідзоленими грунт ми і чорнозем ми опідзоленими, перев жно гідрогенно-тр нсформов ними, поверхнево-глеюв тими і глейовими. вододіл х і схил х 
ч сто поширені к рстові форми з численними глейово-болотними мікрокомплекс ми у скл ді грунтових поєдн нь. розійні поєдн ння відігр ють меншу роль, ніж у горбогірно-лісових місцевостях. пільною рисою грунтового покриву кр ю $є$ бсолютне домінув ння глеюв тих, поверхнево-глеюв тих і глейових грунтів. меж х кр ю виокремлюють сім грунтових округів.

- .2. рунтовий округ орбисте озточчя висотновпорядков них ерозійнодеревоподібних підзолисто-гідроморфних скл дних поєдн нь дерново-сл бкопідзолистих $i$ сірих лісових глеюв тих грунтів з дерновими, лучно-болотними $і$ болотними грунт ми, $\quad$ кож комплексів-т шетів рендзин, лучних, лучно-болотних грунтів 3 торфово-болотними грунт ми і торфовищ, ми прохідних долин.

труктур грунтового покриву визн чен не тільки скл дним рельєфом, й строк тістю грунтотворних і підстильних порід. м лих відст нях чергуються п смові лесові місцевості з в рі ціями ясно-сірих і сірих лісових глеюв тих грунтів, флювіогляці льні й люві льні прохідні долини з комплекс ми дерново-підзолистих, дернових піщ них і супіщ них грунтів з лучно-болотними і болотними грунт ми, круті схили літот мнієвих в пняків і пісковиків 3 моз їк ми рендзин і дернових літогенних (р нкерів) грунтів. меж х округу м йже нем є чорноземів.

- .2.б рунтовий округ смове обужжя ізоморфно-витягнуто- ре льних поєдн нь-в рі иій сірих лісових $i$ темно-сірих опідзолених глеюв тих грунтів 3 чорнозем ми опідзоленими (подекуди типовими) глеюв тими довгих пологих $n$ сом 3 дерновими глейовими, лучно-болотними, торфово-болотними і торфовими грунт ми широкихміжсп смових долин.

основі шести п сом, що простяг ються від озточчя і ьвівського пл то н східпівденний схід до долини хідного угу, з ляг ють верхньокрейдові породи, перекриті товщею легкосуглинкових лесоподібних суглинків. рунтовий покрив п сом сл бкоконтр стний, дрібно ре льний, елемент рні грунтові ре ли перев жно витягнутої форми. коротких випуклих схил х тр пляються сл бкозмиті відміни грунтів. широкій вододільній поверхні инниківського т ижиківського п сом поширені комплекси чорноземів типових з чорнозем ми лучними глейовими, т кож біогенні т шети чорноземів опідзолених і чорноземів типових глеюв тих. мереківському, уликівському т рядецькому п см х поширені поєдн ння-в рі ції сірих лісових $\mathrm{i}$ темно-сірих опідзолених грунтів з дерновими, лучно-болотними і торфово-болотними грунт ми. прип смовій ч стині долин тр пляються комплекси лучно-болотних i мілко похов них торфово-болотних грунтів. центр льній ч стині широких міжп смових долин поширені біогенні т шети торфово-болотних грунтів і глибоких торфовищ.

- .2.в удківсько- ом рнівський округ висотновпорядков них ерозійноглеюв тих поєдн нь-в рі цій сірих лісових $і$ темно-сірих опідзолених глеюв тих грунтів з чорнозем ми глеюв тими $і$ глейовими янсько- ністерської $i$ ородоцькоом рнівської п смових височин.

ростяг ється від кордону 3 ольщею н 3 ході до р. ерещиця н сході. півночі межує 3 дсянською $з$ ндрово- люві льною рівниною. івденн меж проведен по лівому борту долини олозівки і ністр . е моренно-флювіогляці льно- люві льн розчленов н рівнин зі скл дним грунтовим покривом, перев жною рисою якого $є$ сильне профільне оглеєння і текстурн диференці ція профілю грунтів. ільшість ув лів простяг ється у північно-з хідному н прямі, утворюючи з кономірні просторові зміни грунтових мезокомбін цій. оверхні ув лів плоскі бо ледь хвилясті, від чого 
сильно перезволожені, покриті сл бкоконтр стними в рі ціями темно-сірих опідзолених глеюв тих грунтів 3 чорнозем ми гідрогенно-тр нсформов ними глеюв тими i глейовими. собливо поширені ці комбін ції в меж $\mathrm{x}$ оропузького (межиріччя ишня- ерещиця) і ижківського (межиріччя олозівк - ирв - олотвин ) ув лів. ривершинні схили ув лів скл дені висотновпорядков ними в рі ціями сірих і темносірих глеюв тих грунтів різного ступеня змитості. меж х удківської глибоко розчленов ної височини поширені висотновпорядков ні ерозійно-деревоподібні в рі ції ясно-сірих і сірих лісових глеюв тих грунтів н водно-льодовикових відкл д х з численними в лунними г лечник ми у долині p. ишня. іжув лові широкі днищ предст влені комплекс ми чорноземно-лучних грунтів з лучними і лучно-болотними грунт ми.

- .2.2 ввівсько- ирецький округ ізоморфно-плямистих поєдн нь-комплексів сірих лісових глеюв тих грунтів з темно-сірими опідзоленими і чорнозем ми опідзоленими глеюв тими і глейовими хвилястого структурного пл то.

рунтовий округ обмежений чіткими природними меж ми: з з ходу - p. ерещиця, зі сходу - p. убр , з півночі - ілогорще- льчицькою прохідною долиною, з півдня p. ністер. оверхня пл то вкрит ш ром безк рбон тних оглеєних лесоподібних суглинків, підстелених в пняк ми і гіпс ми верхнього тортону. плоскохвилястих вододільних поверхнях пл то розвинений к рстовий мікрорельєф 3 численними глейово-болотними комплекс ми темно-сірих опідзолених, бо сірих лісових глейових грунтів з лучно-болотними і болотними грунт ми. широких ділянк $\mathrm{x}$ долини p. ерещиця (селище еликий юбінь) поширені болотні комплекси чорноземнолучних і лучних глейових грунтів 3 лучно-болотними, $\mathrm{T}$ кож біогенні $\mathrm{T}$ шети торфув то- і торфово-болотних грунтів з торфовищ ми глибокими мілко похов ними.

південь від ьвівського пл то, у б сейні лівих приток ністр ( ирк - ерещиця) поширені висотновпорядков ні ерозійно-деревоподібні поєдн ння сірих лісових i темно-сірих опідзолених глеюв тих грунтів з чорнозем ми опідзоленими глеюв тими і лучно-чорноземними грунт ми. межиріччі ирк - убр по лінії орб чіернопілля- икол їв невеликі площі з йняті поєдн ннями-в рі ціями дерново-сл бкопідзолистих і підзолисто-дернових глеюв тих грунтів н флювіогляці льних супіск х 3 ясно-сірими і сірими лісовими глеюв тими грунт ми н лесоподібних суглинк х.

крутих схил х ерозійно-денуд ційних ост нців і борт х долини р. убр поширені літогенні моз їки підзолисто-дернових глеюв тих грунтів н елювії пісковиків 3 рендзин ми н елювії в пняків. північному з ході пл то, у межиріччі ерещицят вч нк, н водно-льодовикових лесоподібних суглинк х сформув лися в рі ціїплямистості дерново-сл бкопідзолистих і ясно-сірих лісових глеюв тих грунтів 3 лучними, лучно-болотними і торфово-болотними грунт ми широких 6 лок і долин.

- .2.г одорівсько- ог тинський округ висотновпорядков них плямистоерозійних поєдн нь-в рі цій (опідзолення-гумусов ності) сірих лісових $і$ темно-сірих опідзолених грунтів $n$ смово-горбистих височин із чорнозем ми опідзоленими, чорноземно-лучними, лучними $m$ лучно-болотними грунт ми середньотер сового ярусу ністр , долин річок вірж, уг, нил ип, истриця $i$ орон .

відрізку між селищем зупіль і с. ковець р. ністер розділяє округ н дві неодн кові ч стини - лівобережну і пр вобережну. ей округ повністю є в меж х т к зв ного лицького пілля, охоплюючи одорівське і ог тинське пілля, т кож лум цький грунтовий $\mathrm{p}$ йон н пр вобережжі ністр, у межиріччі ністер- 
истриця- орон . івнічн меж округу проведен нижче витоків уги, нилої т олотої ипи. 3 ході округ обмежений рік ми убр, ністер, истриця i орон . нші межі повністю проходять в в но- $p$ нківській обл. південь від лінії одорівові трілищ - ог тин- учинці, у місцевостях третьої н дз пл вної тер си, п нують в рі ції темно-сірих опідзолених грунтів 3 чорнозем ми опідзоленими т їхніми численними змитими н лог ми. 3 ході одорівського пілля, у межиріччі убр уг, серед численних великих лісових м сивів н високих горб х $\mathrm{i}$ крутих схил х поширені ерозійні в рі ції ясно-сірих з сірими лісовими грунт ми; н тер с х, скл дених піщ но-г лечниковими відкл д ми, - моз їки дерново-сл бкопідзолистих грунтів 3 дерновими супіщ ними грунт ми.

- .2.д ологоро- ременецький округ висотновпорядков них ерозійнодеревоподібних поєдн нь-в рі цій сірих лісових $і$ темно-сірих опідзолених глеюв тих грунтів з чорнозем ми опідзоленими глеюв тими, лучно-чорноземними $i$ лучними грунт ми.

круг з йм є верхів'я річкових 6 сейнів видівки, угу, нилої і олотої ип, ерету, кви. ростяг ється довгою вузькою смугою вдовж лого олісся н північний схід від р. убр до р. ілія ( ернопільськ обл.). півночі м є скл дну конфігур цію межі 3 смовим обужжям і лим оліссям, утворюючи численні виступи одільського пл то у формі витягнутих “півостровів" і “островів” одільського пл то і глибоких “з ток” природних комплексів лого олісся з домінув нням висотновпорядков них поєдн нь-моз їк сл бкоопідзолених глеюв тих грунтів з рендзин ми і дерновими літогенними грунт ми високих півостровів і ост нців, і 3 дерново-сл бкопідзолистими і дерновими глеюв тими грунт ми лого олісся. івденн меж проведен вздовж витоків нилої і олотої ип, ерету, д лі простяг ється в інші обл сті. ежі округу приблизно збіг ються з геоморфологічним р йоном ологоро- ременецького горбогір'я. е н йвище піднят і глибоко розчленов н ч стин одільської височини. труктур грунтового покривун південь від оловного вододілу принципово подібн до т кої у меж х одорівсько- ог тинського горбогір'я, 3 винятком повсюдного поверхневого і профільного оглеєння грунтів, т кож зн чного розвитку ерозії, що створює видову строк тість грунтового покриву, скл дну конфігур цію елемент рних грунтових ре лів і грунтових комбін цій. крутих схил х 6 г то дернових грунтів, що входять до скл ду поєдн нь-в рі цій опідзоленняоглеєння як моз їки. орноземи опідзолені з йм ють третину від усієї території округу.

йвищі горби і круті схили предст влені комплекс ми сірих лісових і темно-сірих опідзолених поверхнево-глеюв тих грунтів.

- .2.е ереж нсько- он стириський округ висотновпорядков них ізоморфноерозійних поєдн нь-в рі цій перев жнно сірих лісових з темно-сірими опідзоленими грунт ми, подекуди чорнозем ми опідзоленими глеюв тими одільського горбистого $n$ CM.

оширений н схід від вододілу між річк ми нил i олот ипи. ьвівській обл. $з$ йм є незн чну площу. півночі межує 3 ологоро- ременецьким грунтовим округом.

труктур грунтового покриву визн чен зн чними висот ми місцевості, глибоким (150-200 м) розчленув нням поверхні лівими приток ми ністр (к ньйони олотої ипи i оропця), широкими розвиненими б лк ми, покривним х $\mathrm{p}$ ктером лесоподібних суглинків, інтенсивним розвитком площинної ерозії. ельєф горбистий, вершини 
горбів згл джені, з округлені, без різких форм. менш розчленов них верхів'ях лівих приток ністр в скл ді грунтових поєдн нь зн чну роль відігр ють чорноземи опідзолені. і збільшенням глибини розчленув ння поверхні в н прямі ністр (к ньйоноподібні річищ ) чорноземи опідзолені пр ктично зник ють як елемент структури грунтового покриву. томість н високих горб х, особливо у меж х чи поблизу великих лісових м сивів, поширені в рі ції ясно-сірих і сірих лісових грунтів 3 невеликою ч сткою темно-сірих опідзолених грунтів поблизу широких 6 лок і долин piк. і грунтові комбін ції особливо розвинені в 6 сейн х річок олот ип $і$ оропець у меж х к ньйоноподібних ділянок їхніх долин. середньотер совому ярусі (третя-четверт тер си) ністр, н південь від лінії он стириськ - уч ч, бсолютно домінують в рі ції сірих і темно-сірих опідзолених грунтів. широких 6 лк х $\mathrm{i}$ 3 пл в х рік поширені гідроморфно-болотні комплекси дернових, лучних і лучноболотних грунтів, т кож біогенні т шети торфово-болотних грунтів і торфовищ глибоких мілкопохов них. м, де н крутих схил х елювій глинистих мергелів експонов ний ерозією, сформув лися літогенні моз їки рендзин 3 чорнозем ми к рбон тними і ясно-сірими лісовими грунт ми (поблизу с. ростянець).

ісостепов (лесов) прунтово-біоклім тичн зон. ї 3 хідн меж м скл дну конфігур цію вн слідок глибокої інв зії широколистяно-лісових л ндш фтів уздовж горбогірних м сивів одільської структурно-денуд ційної ерозійної височини.

ьвівській обл. предст влений лише один грунтово-геогр фічний кр й пр вобережної ч стини ісостепової зони.

- .1. хідноподільський кр й із синхронним просторовим чергув нням висотновпорядков них ерозійно-деревоподібних простих поєдн нь-в рі цій (опідзоленняоглеєння) сірих лісових і темно-сірих опідзолених грунтів з чорнозем ми опідзоленими, лучними і лучно-болотними грунт ми горбистих $\kappa$ ньйоноподібних межиріч лівих приток ністр i скл дних в рі цій-плямистостей першого порядку (вилуговув нняоглеєння) чорноземів регр дов них з чорнозем ми типовими (у тому числі к рбон тними $і$ вилугув ними) глибокими глибинно-глеюв тими, лучно-чорноземними $i$ чорноземно-лучними грунт ми широких плоских межиріч і пліоценових прохідних долин.

ей кр й поширений між піллям н 3 ході т одільськими овтр ми н сході. півночі межує 3 ологоро- ременецьким горбогір'ям, н півдні простяг ється до p. рут i отинської височини. ля нього х р ктерн більш гідроморфність грунтів, отже, ч стіш їхня оглеєність, вилугув ність і регр дов ність, порівняно з грунт ми інших грунтово-геогр фічних кр їв лісостепової зони кр їни. ирізняється великою просторовою строк тістю і контр стністю грунтового покриву з вдяки меридіон льному чергув нню плоско-хвилястих рівнинних типів рельєфу ( ернопільське пл то) 3 глибоко- і густорозчленов ними ерозійними форм ми рельєфу придністерського типу.

- .1. борівсько- ліщищький округ плоско-хвилястих місцевостей ернопільської $i$ ридністерської структурно-пл стової рівнин зі скл дними в рі ціямиплямистостями чорноземів регр дов них неоглеєних $i$ глеюв тих з чорнозем ми типовими вилугув ними глеюв тими $i$ глибинно-глеюв тими, лучно-чорноземними $i$ чорноземно-лучними грунт ми.

круг м є меридіон льне поширення і простяг ється від ологоро- ременецького горбогір'я до ністр довгою і порівняно вузькою смугою між одільським горбистим п смом ( піллям) і р. ерет. рунтовий покрив хвилястих межиріч порівняно однорідний, м локонтр стний і предст влений перев жно в рі ціями чорноземів регр дов них 
з лучно-чорноземними і лучними грунт ми. p ктерною особливістю межиріч $є$ н явність фр гментів плоскої, сл бкохвилястої с рм тської морської рівнини з 3 лишк ми неглибоких пологих пліоценових долин південно-східного простяг ння.

меж х ридністерської ч стини округу н ділянк х стрімких, ч сто скелястих к ньйоноподібних долин і прилеглих до них схилів поширені поєдн ння-моз їки темно-сірих регр дов них грунтів і чорноземів регр дов них середньо- і сильнозмитих 3 рендзин ми н літот мнієвих в пняк х і к рбон тних пісковик х нижнього девону.

меж х грунтово-геогр фічної кр їни pn mи ( ) виділено гірсько-буроземний грунтово-геогр фічний пояс (.I.). Цьому поясі виокремлено дв кр ї: ередк р$n$ тський височинний і рп тський гірський.

..1. ередк рп тський височинний кр й з відкритими густодеревоподібноерозійними висотновпорядков ними поєдн ннями-комплекс ми дерново-підзолистих поверхнево-оглеєних, буроземно-підзолистих глеюв тих $i$ люві льних грунтів умеж $х$ ерозійно- кумулятивної височини $i$ тер с. меж х кр ю виділено дві височинні обл сті.

..1. одністерськ тер сов височинн обл сть скл дних поєдн нь-комплексів дернових опідзолених $і$ дерново-середньопідзолистих оглеєних $m$ лучних грунтів тер с з лучними оглеєними ш рув тими, болотними, лучно-болотними грунт ми і торфовищ, ми з пл в ністр $m$ його приток.

..1.б рогобицько- оршинськ передгірн височинн обл сть поєдн ньв рі иій буроземно-підзолистих поверхнево-оглеєних грунтів з дерново-підзолистими поверхнево-оглеєними грунт ми $m$ їхніми еродов ними відмін ми $i$ підзолистодерновими оглеєними грунт ми.

..2. рп тський гірський кр й 3 відкритими сильноконтр стними поєдн ннями-моз їк ми буроземів гірсько-лісових і дерново-буроземних грунтів. меж х кр ю виділено дві гірські обл сті.

..2. т рос мбірськ гірськ обл сть поєдн нь-моз їк буроземів гірсько-лісових і буроземно-підзолистих поверхнево-глеюв тих грунтів з дерново- $і$ лучно-буроземними оглеєними грунт ми.

. 2.б урківсько- колівськ гірськ обл сть поєдн нь-моз їк буроземів гірськолісових і глибокодерново-буроземних з лучно-буроземними глейовими грунт ми.

веден схем $\mathrm{p}$ йонув ння розроблен до рівня округів. рунтово-геогр фічн дет ліз ція округів н рівні $\mathrm{p}$ йонів потребує дет льних польових досліджень із з стосув нням ст тистико-к ртогр фічних методів н лізу структури грунтового покриву. ьогодні це неможливо викон ти, тому як грунтово-геогр фічні р йони скл дові грунтових округів - 3 пропонов но використовув ти (ч стково змінивши) д ні грогрунтового р йонув ння.

1. ндрущенко . . грогрунтові р йони кр їнських рп т // грохімія і грунтозн вство. иїв : рож й, 1969. ип. 12. . 172-200.

2. ерн ндер . . грогрунтові р йони кр їнського олісся // грохімія і грунтозн вство. иїв : рож й, 1969. ип. 12. . 27-61.

3. ськевич . ., озняк . . труктур грунтового покриву ологороременецького горбогір'я : моногр фія. ьвів : ид. центр ім. . p нк, 2007. $208 \mathrm{c}$. 

ISSN 2078-6441. Вісник Львівського університету. Серія географічна. 2018. Випуск 52

4. г льне геоморфологічне р йонув ння території кр їни / ред. . . лієнко, . . рщевського, . . ортник т ін. // кр їнський геогр фічний журн л. 2004. № 1. . 3-11.

5. исель . . очвенный покров и $\mathrm{p}$ йониров ние черноземной территории кр ины // ерноземы ( кр ин ). оскв : олос, 1981. . 26-37.

6. піш . ., озняк . . рунтово-геогр фічне р йонув ння : ст новлення, нові підходи // кр їнський геогр фічний журн л. 2012. № 2. 18-22.

7. піш . ., озняк . ., в нюк . ., мелинець . . рунтово-геогр фічне p йонув ння кр їнського олісся // укові з писки ернопільського н ціон льного пед гогічного університету ім. . н тюк . ерія: еогр фія. ернопіль :

“ йп”, 2016. № 2 (вип. 41). . 31-42.

8. дзій . ., озняк . . труктур грунтового покриву олинської височини : моногр фія/ уцьк: “еж” “е ім. есі кр їнки, 2009. 208 с.

9. корин . . грогрунтові р йони ісостепу пр вобережного т 3 хідного // грохімія і грунтозн вство. иїв : рож й, 1969. ип. 12. . 91-108.

10. ридл нд . . труктур почвенного покров . оскв : ысль, 1972. 423 с.

\section{REFERENCES}

1. Andrushchenko, G. O. (1969). Agro-soil regions of the Ukrainian Carpathians. Agrochemistry and soil science, 12. Kiev: Urozhay, 172-200 (in Ukrainian).

2. Vernander, N. B. (1969). Agro-soil regions of Ukrainian Polissya. Agrochemistry and soil science, 12. Kiev: Urozhay, 27-61 (in Ukrainian).

3. Gaskevich, O. V., \& Poznyak, S. P. (2007). The structure of the soil cover of the Hologoro-Kremenets hillboreen. Lviv: Publ. Center of LNU by I. Franko, 208 pp. (in Ukrainian).

4. Palienko, V. P., Barchevsky, M. E., Bortnik, S. Yu., \& others (Eds.). (2004). General geomorphological zonation of the territory of Ukraine. Ukrainian Geographic Journal, 1, 3-11 (in Ukrainian).

5. Kiselev, V. D. (1981). Soil cover and zonation of the chernozem areal of Ukraine. Chernozems of the USSR (Ukraine) (pp. 26-37). Moscow: Kolos, 1981 (in Russian).

6. Papish, I. Ya., \& Poznyak, S. P. (2012). Soil-geographical zonation: establishment, new approaches. Ukrainian Geographical Journal, 2, 18-22 (in Ukrainian).

7. Papish, I. Ya., Poznyak, S. P., Ivanyuk, G. S., \& Yamelynets, T. S. (2016). Soilgeographical zonation of the Ukrainian Polissya. Scientific Notes of Ternopil National Pedagogical University by V. Hnatyuk. Series Geography, 2(41). Ternopil: SMP “Tayp”, 31-42 (in Ukrainian).

8. Radziy, V. V., \& Poznyak, S. P. (2009). The structure of the soil cover of the Volyn region. Lutsk: RVV "Vezha" of the VNU by Lesia Ukrainka, 208 p. (in Ukrainian).

9. Skorina, S. O. (1969). Agro-soil regions of the right-bank and western Forest-steppe. Agrochemistry and soil science, 12. Kiev: Urozhay, 91-108 (in Ukrainian).

10. Friedland, V. M. (1972). The structure of the soil cover. Moscow: Mysl, 423 pp. (in Russian).

m ття: н дійшл до ред кцї̈ 20.04.2018

доопр цьов н 24.05.2018

прийнят до друку 12.06.2018 


\title{
SOIL-GEOGRAPHICAL ZONATION OF LVIV OBLAST: STRUCTURE AND PRINCIPLES
}

\author{
Stepan Poznyak, Ihor Papish, Halyna Ivaniuk, Taras Yamelynets \\ Ivan Franko National University of Lviv, \\ P. Doroshenko St., 41, UA - 79007 Lviv, Ukraine, \\ e-mail: stepan.pozniak@lnu.edu.ua,igor_papish@ukr.net,ivanyukhs@gmail.com, \\ taras.yamelynets@gmail.com
}

The scheme of soil-geographical zonation of Lviv oblast is developed on the principles of structural approach to the spatial organization of soil cover. Criteria for allocation of the ranked taxonomic units, their spatial and genetic properties are qualitative and genetic indicators of soil cover with the analysis of the spatial arrangement of soil combinations and structures.

The following taxonomic units are identified in the proposed scheme of soil-geographical zonation: soil-geographic kraina (soil-geographic country), soil-bioclimatic zona/poias (soil-geographic zone/mountain belt), krai (region), okrug (county or mountainous soil region), rayon (district), masyv (massif).

A mandatory criterion for all taxonomic units of soil-geographical zonation is the type of soil cover mesostructures (spatial-geometric characteristics of elemental soil areals and their spatial structures, as well as the dominated class of soil combinations).

Two soil-geographic kraina (countries) are identified within Lviv oblast: the East European Plain and the Carpathians; three soil-bioclimatic zones: moraine-sander (popilnyakova) zone of mixed forests, broadleaf forest, forest-steppe (loess) and mountain-brownsoil zone; six soil krai: Malopoliskyi, Volynskyi, Roztots'ko-Opilskyi, Zahidnopodilskyi, Peredkarpatskyi highland, the Carpathian mountain; 13 soil counties and 4 regions.

Key words: zonation, soil cover structure, zone, krai, okrug, Lviv oblast. 